\title{
SEISMIC INVESTIGATION IN THE BERTIOGA COASTAL PLAIN, BRAZIL
}

\author{
Emilio Eduardo Moreira Barbosa ${ }^{1}$, Renato Luiz Prado ${ }^{1}$, Matheus Cafaro Arouca Sobreira ${ }^{1}$, \\ Rodrigo Dias Samões ${ }^{1}$ and Célia Regina de Gouveia Souza ${ }^{2}$
}

Recebido em 8 novembro, 2011 / Aceito em 29 maio, 2012

Received on November 8, 2011 / Accepted on May 29, 2012

\begin{abstract}
This paper presents results of seismic data from shallow seismic reflection onshore acquisition in the coastal plain of Bertioga (São Paulo State, Brazil) in order to support studies of its geological-geomorphological evolution. By using data from a CMP survey, we sought to analyze and interpret the record of three distinct events: reflected waves, refracted waves and surface waves. From the data processing, three sections were generated: stacked section of the reflected waves, tomographic section from the inversion of travel times of refracted $\mathrm{P}$ waves, and S-wave velocity section obtained from the inversion of dispersion curves of surface waves. The integration provided a detailed geological section with information about important contacts of quaternary units, surface of the basement rock and a geological structure that suggests a quaternary reactivation of an inferred fault.
\end{abstract}

Keywords: seismic methods, coastal plain of Bertioga, quaternary deposits.

RESUMO. Este trabalho apresenta resultados da interpretação de dados obtidos em uma aquisição de sísmica de reflexão rasa onshore na planície costeira de Bertioga (São Paulo) visando subsidiar estudos da sua evolução geológica-geomorfológica. Utilizando-se dos dados de um único levantamento CMP, buscou-se analisar e interpretar o registro de três eventos distintos: ondas refletidas, ondas refratadas e ondas de superfície. Do processamento dos dados foram geradas: seção empilhada das ondas refletidas, seção tomográfica da inversão dos tempos de percurso das ondas $\mathrm{P}$ refratadas e seção de velocidades das ondas $\mathrm{S}$, obtida a partir da inversão das curvas de dispersão das ondas de superfície. A integração forneceu uma seção geológica detalhada com informações de contatos importantes entre unidades quaternárias, superfície do embasamento rochoso, e estrutura que sugere reativação quaternária de falha inferida.

Palavras-chave: métodos sísmicos, planície costeira de Bertioga, depósitos sedimentares quaternários.

\footnotetext{
${ }^{1}$ Instituto de Astronomia, Geofísica e Ciências Atmosféricas, Universidade de São Paulo, Rua do Matão, 1226, 05508-090 Cidade Universitária, São Paulo, SP, Brazil. Phone: +55 (11) 3091-2762; Fax: +55 (11) 3091-5034 - E-mails: emilio_facu@hotmail.com; renato@iag.usp.br; matheuscaf@hotmail.com;

rodrigo.samoes@gmail.com

2 Instituto Geológico do Estado de São Paulo, Avenida Miguel Stéfano, 3900, 04301-903 Água Funda, São Paulo, SP, Brazil. Mailbox: 8772. Phone: +55 (11) 5073-5511; Extension: 2050; Fax: +55 (11) 5073-5511 - E-mail: celia@igeologico.sp.gov.br
} 


\section{INTRODUCTION}

The coastal plains of the São Paulo State have been the target of many geoscientific studies (Suguio \& Martin, 1976, 1978; Giannini, 1987; Suguio \& Tessler, 1992; Souza, 2007), as they present important data about the geological-geomorphological evolution of the Quaternary of Brazil. These studies have also been used as basis for land management policies and the management of natural resources as these areas have been suffering continuous degradation.

However, reports of direct investigations of the subsurface, as well as of shallow seismic investigations focused on the interpretation of quaternary evolution of the São Paulo coastal plains are rare. A few papers can be mentioned presenting offshore shallow seismic studies, such as: Tessler \& Souza (1998), Mahiques \& Souza (1999), Paolo \& Mahiques (2008).

The coastal plain of Bertioga is of particular importance for the geological study, as it comprises all types of deposits present in the São Paulo coast (Souza, 2007; Souza et al., 2008), aside from bringing data of the quaternary tectonic activity during its geomorphological development (Souza \& Souza, 2001), as it seems to have happened in other locations of the Southeastern coast of Brazil (Suguio, 2010).

The relevance of this paper is associated to the scarcity of reports of onshore reflection seismic investigation in quaternary environments of the Brazilian coastal plain, in the same scale of the shallow investigation presented in this paper. Furthermore, the objective here was to analyze and interpret three distinct events using data from a single CMP survey (common midpoint): reflected waves, refracted waves and surface waves.

The processing of the data provided: stacked section of reflected waves; tomographic section from the inversion of traveltimes of refracted $\mathrm{P}$ waves, and S-wave velocity section, obtained from the inversion of the dispersion curves of the surface waves.

The integration of the results obtained in each analysis provided an interpreted section of a transect perpendicular to the coastline.

\section{GEOLOGICAL BACKGROUND}

The Bertioga coastal plain is located in the central coast of the São Paulo State, over an extension of $45 \mathrm{~km}$ with a maximum width of approximately $8 \mathrm{~km}$ (Suguio \& Martin, 1978). It is limited by the mouth of the Bertioga Channel (to the west), the estuary of the Itapanhaú river and the borders of the Atlantic Plateau or the Serra do Mar mountain range (to the North), the Atlantic Ocean (to the South) and the area adjacent to the coastal plain of the district of São Sebastião (to the East) (Fig. 1).
In the Bertioga region the crystalline basement of the Serra do Mar mountain range and the isolated hills in the coastal plains are made up of gneiss, migmatites and oftalmites of the Brasiliano Cycle, therefore of Precambrian age (Fierz, 2008). Basic dykes, generated during the Wealdeniana Reactivation (Mesozoic) are also present, mainly observed in the crystalline costal cliffs.

Souza (2007) mapped the sedimentary environments of the coastline, the coastal plain and the low-to-medium hills of Bertioga, calling them Quaternary Geomorphological-Geological Units (QU) (Fig. 1). This classification used the classic methods of geological mapping of quaternary units defining the units through the principle of homogeneous zone.

Figure 1 also identify the locations I and II (LI and LII) where the seismic walkaway noise tests were carried out. LI is located in the Cx-LPTa/LCD unit, a complex made up of Pleistocene raised marine terraces associated to palaeo-estuarine-lagoonal depressions (lagoonal and estuarine sediments) that were active, at least, during the Holocene (Santos Transgressive-Regressive event) and filled with continental deposits after the marine regression (fluvial, lacustrine and paludal sediments) from Holocene to present. LI is located in the LCD unit, made up of palaeo-estuarine-lagoonal depressions (lagoonal and estuarine sediments) active, at least, during the Holocene (Santos Transgressive-Regressive event) and filled with continental deposits after the marine regression (fluvial, lacustrine and paludal sediments) from the more recent Holocene to the present.

\section{METHODOLOGY}

\section{Walkaway Noise Tests}

The walkaway noise tests were carried out in sites of easy access, low level of urban noise, and where the seismic line could be extended for more than $1 \mathrm{~km}$. Moreover, they represented sites of geological relevance for the study, since the geological map of Souza (2007) (Fig. 1) indicates, in both areas, occurrence of sedimentary deposits from the Pleistocene and Holocene (CXLPTa/LCD and LCD). One of the goals of the seismic investigation was to map these contacts in the subsurface.

In the walkaway noise tests two types of sources were tested: an impact source using a $8 \mathrm{~kg}$ sledge hammer; and a repetitive source using a vibrator soil compactor, making use of the MiniSosie technique (Barbier et al., 1976). Geophones with naturalfrequency of $40 \mathrm{~Hz}$ were used, with a spacing of $1 \mathrm{~m}$, with a minimum offset of $1 \mathrm{~m}$, and 4 Geode seismographs (Geometrics Inc.), linked in a network, adding up to 96 acquisition channels. 


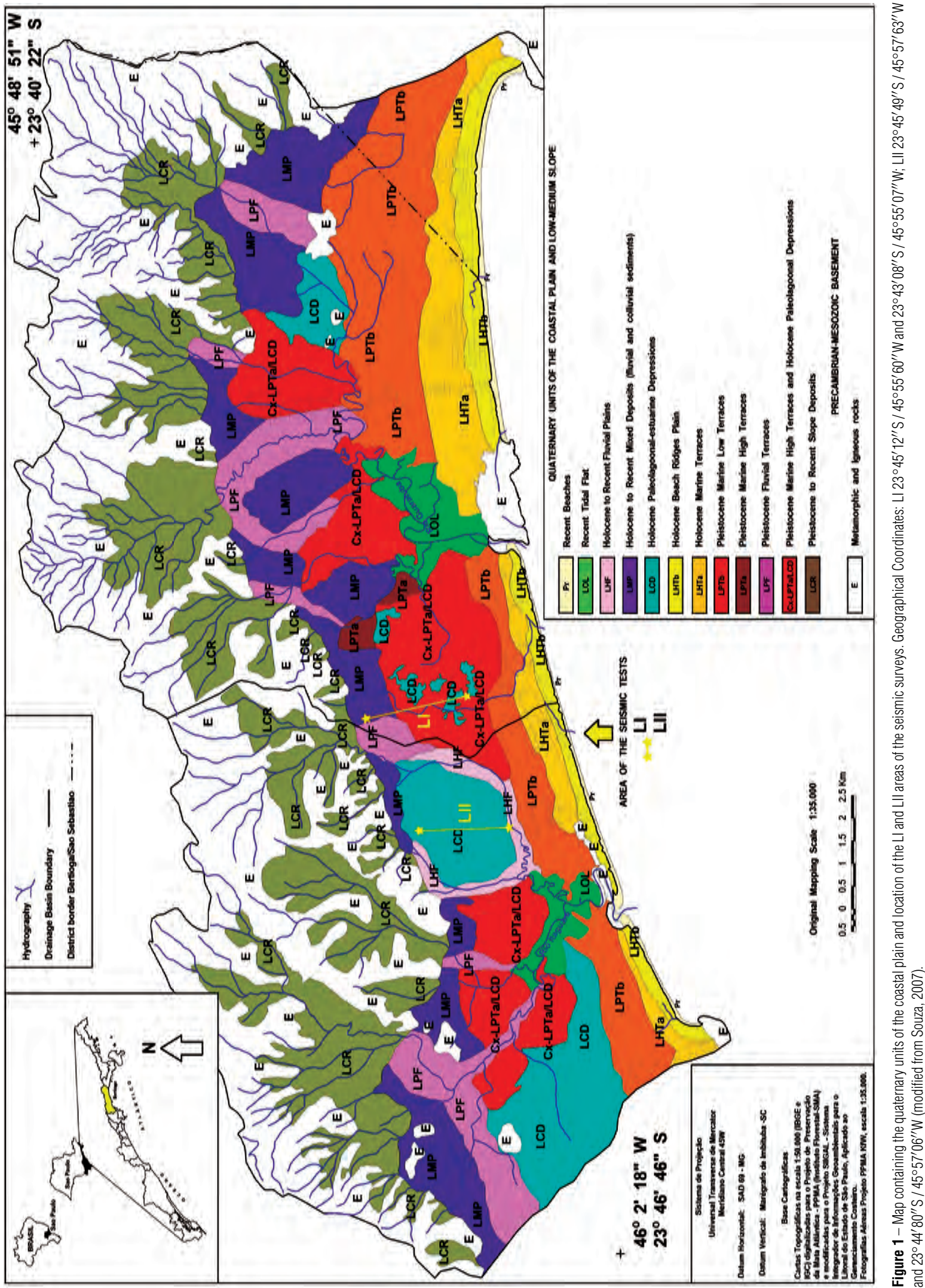




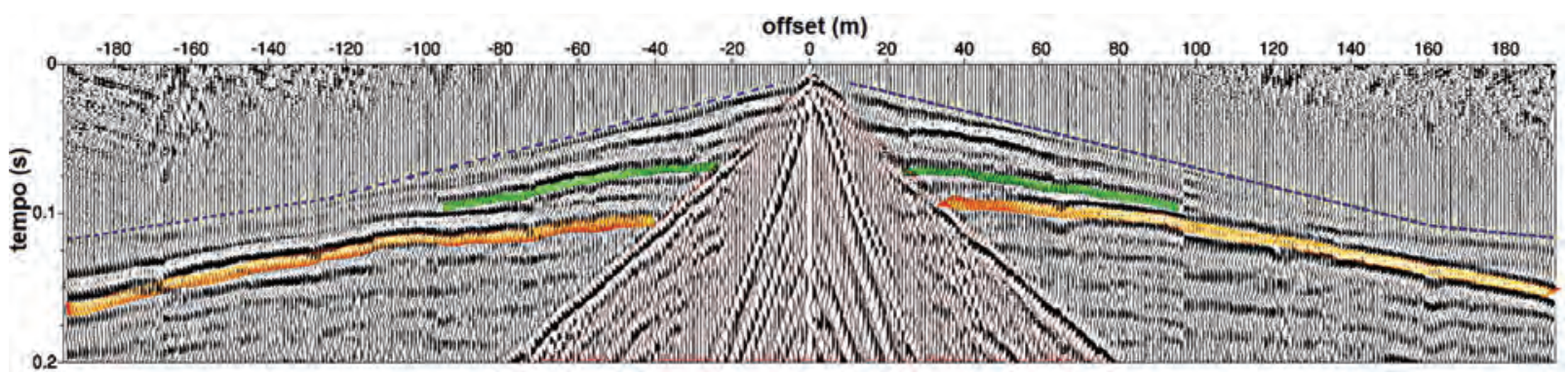

Figure 2 - Seismograms of the walkaway noise tests at location LII. The blue dashed line corresponds to the refraction event, the red area, to the surface waves. The reflection event in green is a sediment-sediment contact, and, in orange, the sediment-basement contact. $40 \mathrm{~Hz}$ geophones with $1 \mathrm{~m}$ spacing were used.

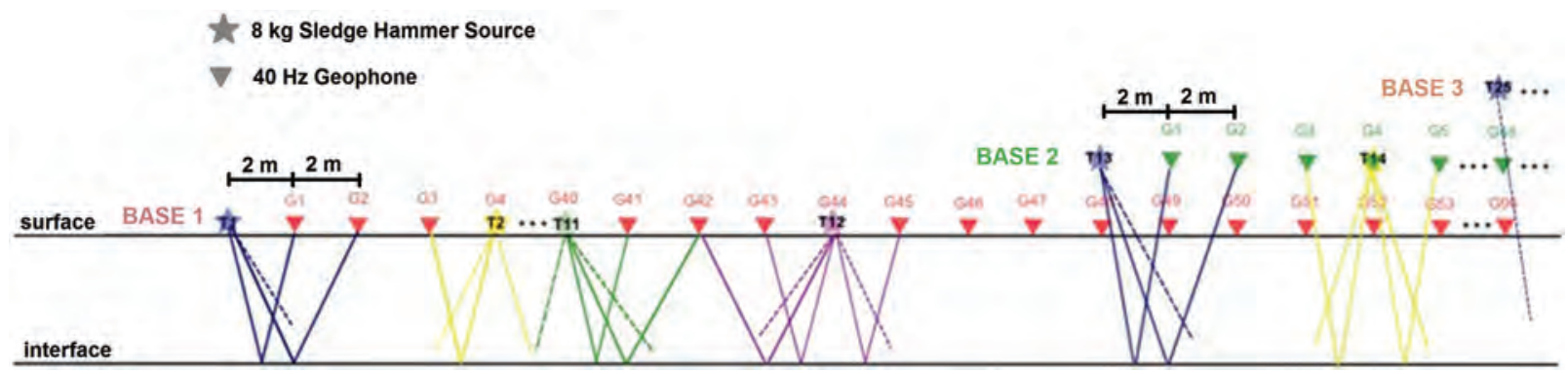

Figure 3 - Illustration of the acquisition geometry adopted. The first shot (T1) was fired two meters away from the first geophone (G1), having been moved in intervals of eight meters towards the center of the spread. After the completion of 12 shots, the first 48 geophones were moved to the end of the spread and the source once again to two meters from the first geophone.

In the two areas where the walkaway noise tests were performed two records were made, with the source being positioned to the right and to the left of the geophones array, both with a minimum offset of $1 \mathrm{~m}$. Both seismograms at site LII (to the right and to the left of the array) were joined, to facilitate the interpretation of the observed events (Fig. 2).

\section{CMP acquisition and data processing}

After the analysis of the noise tests, LII was chosen (Figs. 1, 2) for the CMP acquisition due to the better quality of the records obtained in this area. The sledge hammer source presented a better response compared to that obtained from the compactor, and was used in the CMP acquisition.

The geometry adopted in the CMP acquisition was based on the work of Diogo et al. (2004), moving half of the geophone spread (48) every sequence of 12 shots (Fig. 3). The shot sequence was performed in the beach-escarpment direction (SENW). The first shot (T1) was fired two meters away from the first geophone (G1), and the following shots were fired every eight meters towards the center of the spread. After the completion of 12 shots, the first 48 geophones were moved to the end of the spread, and the acquisition continued with the same pattern. At the end a total of 180 shots were acquired, making up for a seismic line of approximately $1.5 \mathrm{~km}$ and 12-fold coverage.

After acquisition of the CMP data, three distinct processing sequences were carried out, depending on the event being analyzed: reflected, refracted and surface waves.

For the P-wave reflection data, the basic processing flowchart for the CMP acquisition was applied, using the Seismic Unix SU software (Cohen \& Stockwell Jr., 2010). This included: trace edition (conversion of the formats seg2 $\rightarrow$ segy $\rightarrow$ su, setting acquisition geometry, mute filtering), amplitude balancing (Automatic Gain Control - AGC), band-pass frequency filter, F$\mathrm{K}$ filter, CMP sorting, velocity analysis (constant velocity stacking panel and semblance panel), NMO correction, stacking, migration, time-depth conversion.

The tomographic processing of the refraction data was performed with the Rayfract ${ }^{\circledR}$ software, starting with the first arrival travel time picks of the $\mathrm{P}$ waves from all the same 180 shot seismograms used in the processing of reflection seismic data. The Rayfract ${ }^{\circledR}$ software uses the WET inversion method - Wavepath Eikonal Travel time (Schuster \& Quintus-Bosz, 1993). The WET inversion is based on a back projection algorithm for inverting velocities from travel times computed by finite-difference solution to the eikonal equation (Lecomte et al., 2000). The initial velocitydepth model is generated by the method Delta-t- $V$ of Gebrande \& Miller (1985 apud Rohdewald, 2011). 


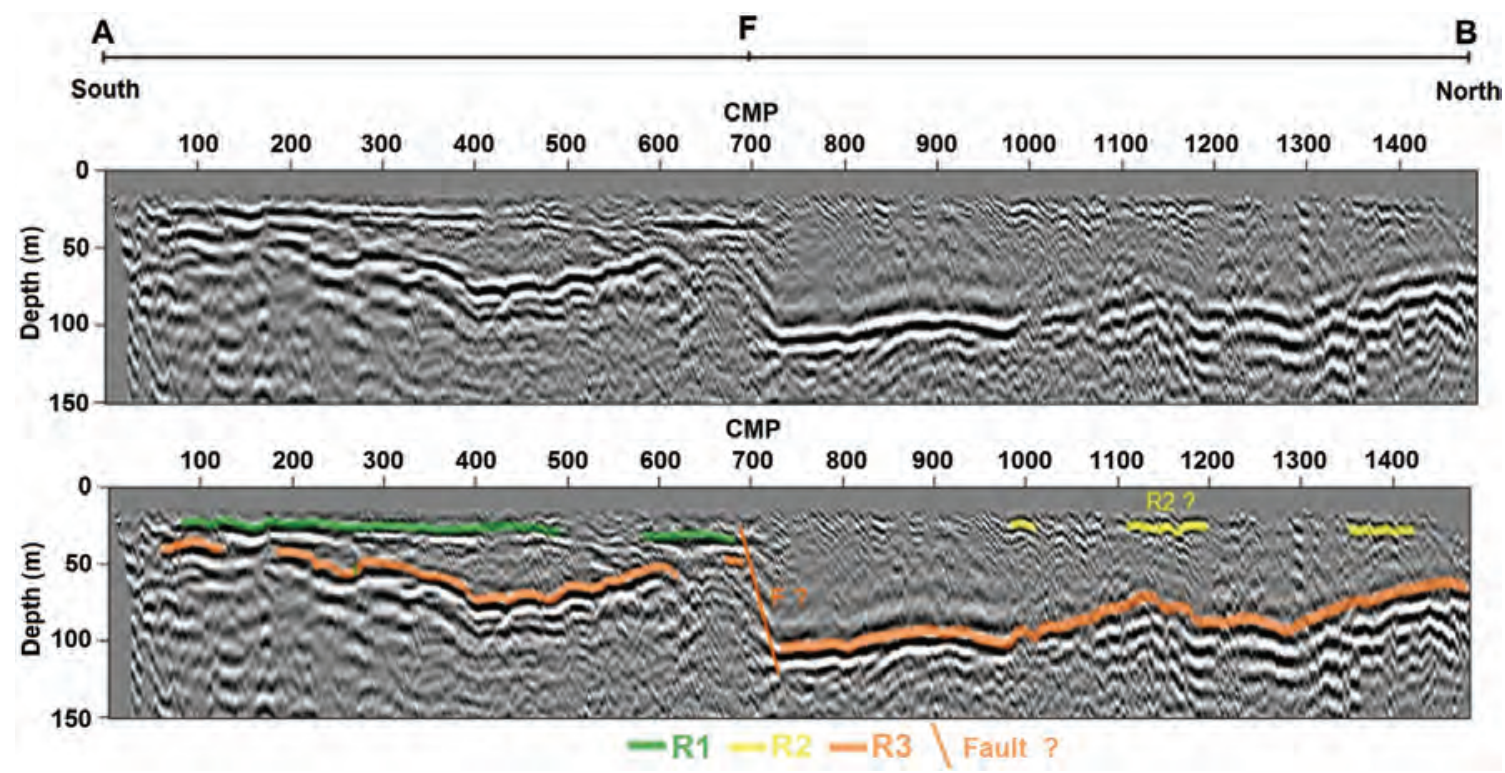

Figure 4 - Stacked section converted from time to depth after the use of an AGC gain, bandpass and mute filters, and the same interpreted section, with the indication of the reflectors $R 1, R 2$ and $R 3$ and the $F$ fault inferred. The segment $F B$ was affected by the reactivation of the fault.

Finally, for the processing of surface wave data (Rayleigh) using the MASW method (Multichannel Analysis of Surface Waves) the Surfseis ${ }^{\circledR}$ software (Park et al., 1999) was used. The processing consists in the transformation of the wave field recorded in the shot gather seismogram in order to obtain the image of the dispersion and extraction of experimental dispersion curve. The dispersion image represents the sum of the amplitude values in each offset $(x)$ for each frequency being considered. The sum is made after the application of a phase shift $(\varphi)$ dependent on the offset, and repeated for each one of the phase-velocity values considered. After extracting the dispersion curve, the inversion processes (Xia et al., 1999) are used to infer a velocity profile of the shear waves $(S)$ in the subsurface, based on the dispersive behavior of the surface waves as they propagate in a vertically heterogeneous environment and in the existing relationship between the velocities of the Rayleigh waves and the $S$ waves.

\section{RESULTS AND DISCUSSION}

The walkaway seismograms (Fig. 2) indicated the occurrence of two probable reflections that were later confirmed in almost all the CMP gathers, and resulted in the interfaces interpreted in the final stacked section. The refractions were also easily identified along the whole geophone spread (up to offsets close to $200 \mathrm{~m}$ ), as well as the surface waves, always predominant in the seismograms of shallow investigations.
Figure 4 presents the depth stacked section obtained after processing the reflection data, and its interpretation. Figures 5 and 6 present, respectively, the sections obtained from the tomography of the refraction data and from the spectral analysis of the surface waves.

Figure 7 presents the interpreted section that integrates the information obtained from the three methods used.

It was possible to identify three interfaces in the stacked seismic section (seismic reflectors R1, R2 and R3). Seismic reflector R3 is associated to the contact sediment-basement (confirmed through the refraction data in some shot gather seismograms) and the $\mathrm{R} 2$ is a contact between sedimentary packages. Seismic reflector $\mathrm{R} 2$ is discontinuous and is only seen in some sectors of the section (segment FB of Fig. 4).

The subsurface images generated by the MASW and tomography methods of the refracted $P$ waves permitted to map additional interfaces other than those interpreted by the seismic reflection method. The interfaces were inferred from seismic velocity contrasts in images shown in Figures 5 and 6.

The tomographic inversion shows, in some sectors of the tomogram the basement interface intervals of 0 to $400 \mathrm{~m}$ and 1200 to 1500 m, approximately (Fig. 5-I). However, refraction arrivals from the basement were only recorded in some shot gathers. The raypath density image resulted from the inversion process (Fig. 5-II) presents a low density of rays in depths greater than approximately 20 meters. For this reason, the interpretation of the refraction data was only considered up to this depth. 


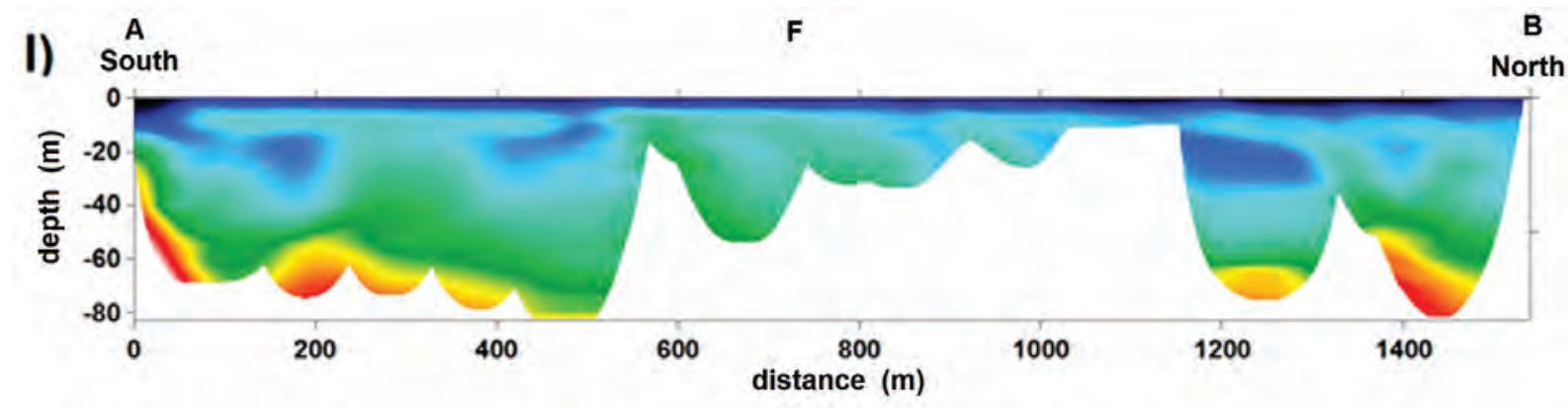

50010001500200025003000350040004500

P-wave velocity $(\mathrm{m} / \mathrm{s})$
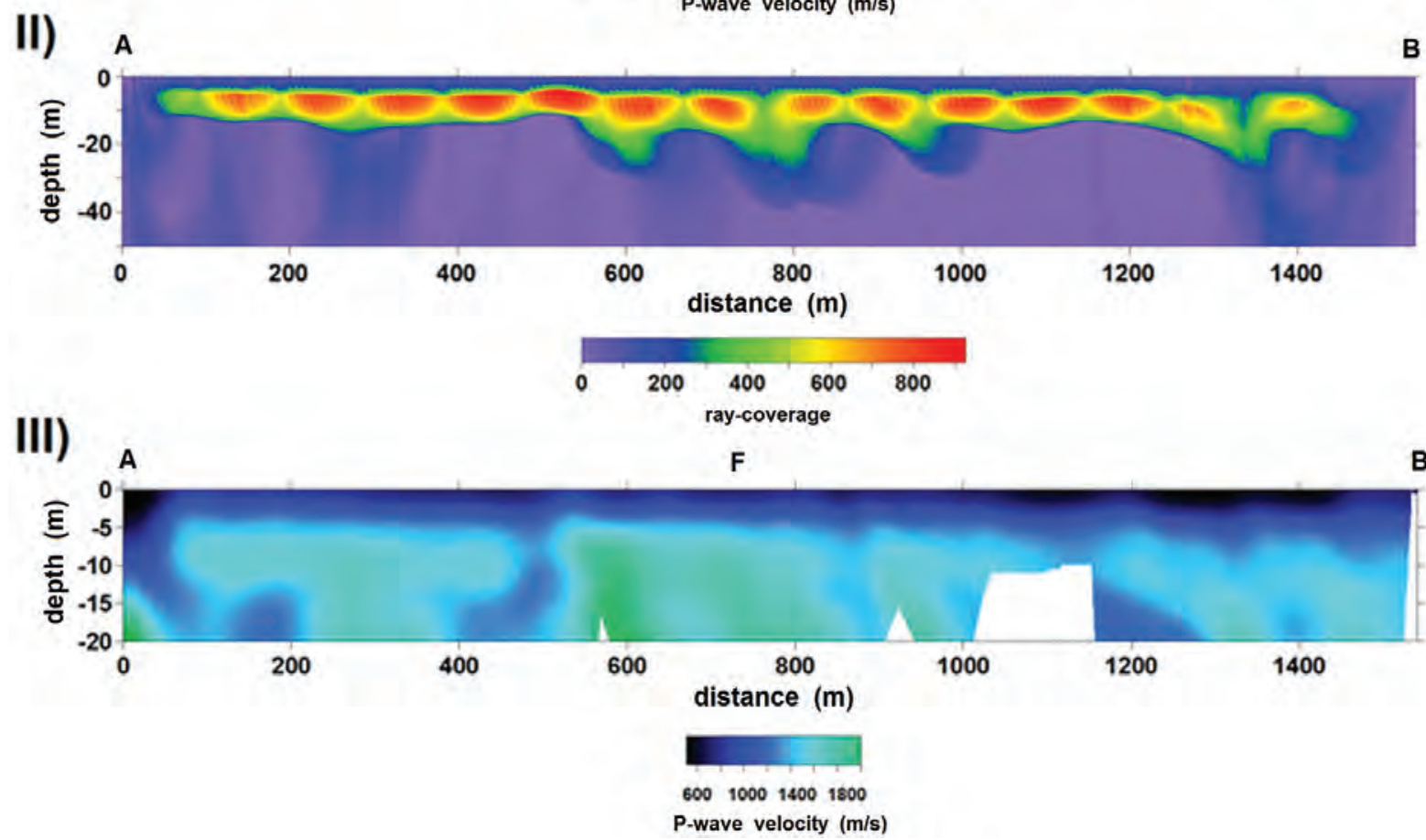

Figure 5 - P-wave velocities model obtained using the tomography of the refracted P waves travel times (I); Raypath coverage image (II); Detail of the inversion (presented in I) up to $20 \mathrm{~m}$ of depth (III).

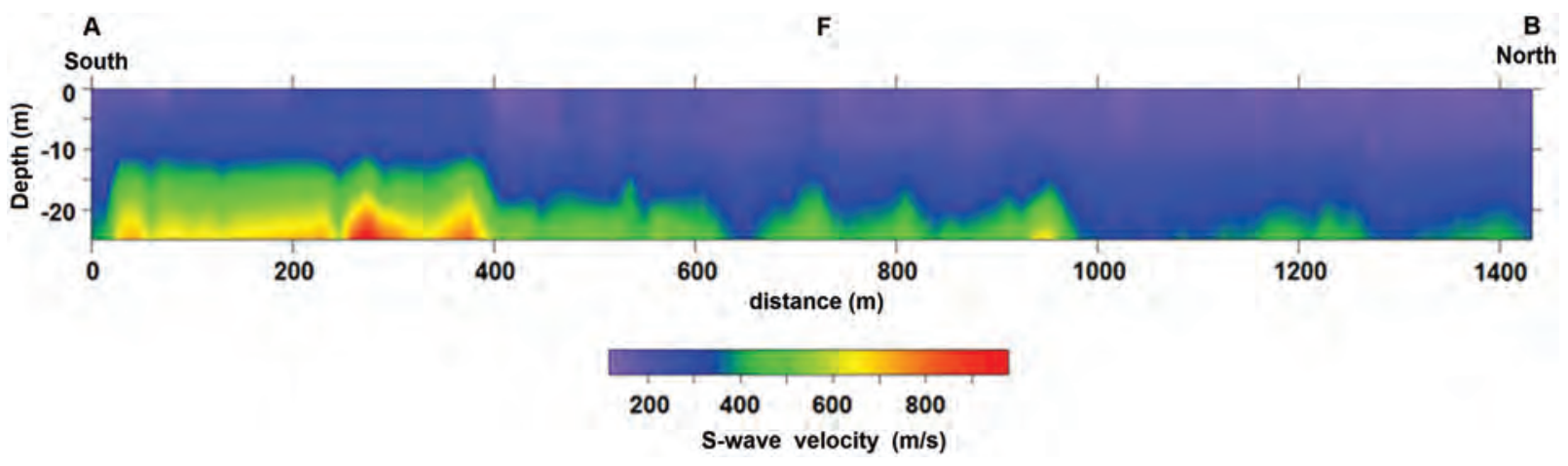

Figure 6 - S-wave velocities model, resulting from the interpolation of the profiles after inversion of the dispersion curves using the MASW method. 


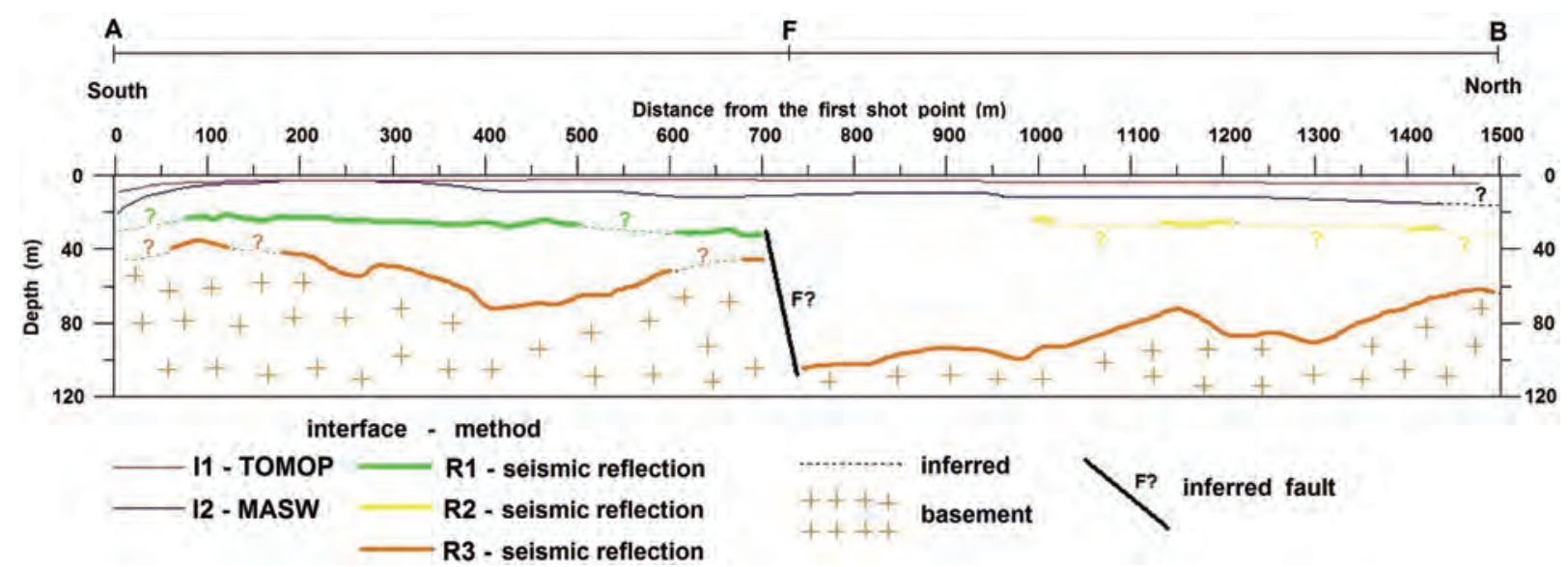

Figure 7 - Integrated section presenting the results obtained from the seismic reflection, tomography of the refracted $\mathrm{P}$ waves, and analysis of the surface waves methods. The segment AF and the superficial sedimentary layers above the R1 and R2 were not affected by the fault.

The units mapped using the refraction tomography and MASW methods are, probably, associated to the more recent deposits (fluvial, lacustrine and paludal), on average, having thickness lesser than 15 meters.

The analysis of the surface waves allowed differentiating one interface within these sediments, not mapped by the P-wave analysis (whether through the refraction or reflection method). This contact should limit sediments with distinct elastic properties, but since it is below the water table it was only mapped through the analysis of the $S$ waves velocity contrast.

In relation to the propagation velocities of the seismic waves, the joint analysis of the results obtained using the refraction and MASW methods for the superficial horizons, reveals a high Vp/Vs ratio which is mainly associated to the saturation of sediments, since the local water level is quite shallow. In these conditions the velocity of the S-wave is not greatly affected by the degree of saturation, as happens with the P-wave. The order of magnitude observed is consistent with those found in the literature for similar sediments. Stuempel et al. (1984), having compiled results from seismic tests of refraction, reflection and drilling holes obtained in saturated shallow sediments in the Northern Germany, report high values for the Vp/Ns ratio, even for those partially saturated, and extremely high values for clayey horizons.

Therefore, it is possible to observe that the tomographic section and the one obtained using the MASW method were efficient to map the shallower interfaces, whereas the analysis of reflected waves allowed for the mapping of deeper horizons.

\section{CONCLUSIONS}

The results showed that the integration of the three methods makes up for an important tool for mapping the shallow sub- surface of onshore coastal areas. The integration of seismic reflection, the MASW method and the refracted waves tomography method, using the same seismic data acquired in a standard CMP acquisition (originally used in seismic reflection method), provides a more complete geological section, and important subsidies for the geological study.

The seismic reflection, alone, has proven to be an effective method to map the top of the crystalline basement (R3) and also the interfaces between distinct sedimentary units (R1). In this last case, it is admitted that such reflective surface indicates the existence of sediments with significant differences in terms of compaction, density and consequently acoustic impedances. It is possible to infer from the geological map information that such contact (R1) may be the limit between the Holocene and the Pleistocene units.

The method also permitted to map an important geological structure, the normal fault observed at the center of the section, shown as a clear discontinuity of the $\mathrm{R} 1$ seismic reflector within the segment FB of the seismic section. The seismic reflection method did not present enough resolution to map shallower and recent sedimentary deposits.

However, the MASW and tomography methods, were effective to map the shallower sedimentary deposits.

Therefore, the seismic reflection CMP record, even not being the ideal data to be analyzed by the MASW and tomography methods, may be used in the interpretation of refracted and surface waves, as they present details of the shallower subsurface, impossible to map through usual seismic reflection procedures. For this, in the initial walkaway tests, aiming at defining the geometry of CMP acquisition, one should have a closer look 
at these other events, mainly to surface waves, usually considered undesirable noise in seismic reflection acquisitions.

\section{ACKNOWLEDGEMENTS}

The authors would like to express their appreciation to the Conselho Nacional de Desenvolvimento Científico e Tecnológico - CNPq (Project 477482/2009-0) and to the Fundação de Amparo à Pesquisa do Estado de São Paulo - FAPESP (Project 2008/58549-0) for the financial support in carrying out this research.

\section{REFERENCES}

BARBIER MG, BONDON P, MELLINGER R \& VIALLIX JR. 1976. MiniSosie for land seismology. Geophysical Prospecting, 24: 518-527.

COHEN JK \& STOCKWELL Jr JW. 2010. CWP/SU: Seismic Unix Release №. 42: an open source software package for seismic research and processing. Center for Wave Phenomena, Colorado School of Mines. $135 \mathrm{pp}$.

DIOGO LA, LE DIAGON FMM \& PRADO RL. 2004. Bedrock imaging using post-critical shallow seismic reflection data. Journal of Applied Geophysics, 57(1): 1-9.

FIERZ MS. 2008. As abordagens sistêmicas e do equilíbrio dinâmico na análise da fragilidade ambiental do litoral do estado de São Paulo: contribuição à geomorfologia das planícies costeiras. Doctorate Thesis, Faculdade de Filosofia, Letras e Ciências Humanas, Universidade de São Paulo. 410 pp.

GIANNINI PCF. 1987. Sedimentação Quaternária na Planície Costeira de Peruíbe-Itanhaém (SP). M.Sc. Dissertation, Instituto de Geociências, Universidade de São Paulo. 234 pp.

LECOMTE I, GJØYSTDAL H, DAHLE A \& PEDERSEN OC. 2000. Improving modelling and inversion in refraction seismics with a first-order Eikonal solver. Geophysical Prospecting, 48: 437-454.

MAHIQUES MM \& SOUZA LAP. 1999. Shallow seismic reflectors and upper Quaternary sea level changes in the Ubatuba region, São Paulo State, Southeastern Brazil. Revista Brasileira de Oceanografia, 47(1): $1-10$.

PAOLO FS \& MAHIQUES MM. 2008. Utilização de métodos acústicos em estudos de dinâmica costeira: Exemplo na desembocadura lagunar de Cananéia. Revista Brasileira de Geofísica, 26(2): 211-225.

PARK CB, MILLER RD \& XIA J. 1999. Multimodal analysis of high frequency surface wave. In: Proceedings of the Symposium on the Application of Geophysics to Engineering and Environmental Problems (SAGEEP 99), Oakland, CA, March 14-18, p. 115-122.
ROHDEWALD SR. 2011. Interpretation of first-arrival travel times with Wavepath Eikonal Traveltime Inversion and Wavefront Refraction method. In: EEGS Symposium on the Application of Geophysics to Engineering Environmental Problems, 24., 2011, Charleston. CD-ROM.

SCHUSTER GT \& QUINTUS-BOSZ A. 1993. Wavepath Eikonal Traveltime Inversion: Theory. Geophysics, 58(9): 1314-1323.

SOUZA CRG. 2007. Ambientes sedimentares de planície costeira e baixa-média encosta em Bertioga (SP). In: Congresso da Associação Brasileira de Estudos do Quaternário, 11., 2007, Belém. Proceedings... São Paulo: ABEQUA. CD-ROM.

SOUZA CRG \& SOUZA AP. 2001. Evidências de atividade tectônica quaternária no litoral paulista. In: Congresso da Associação Brasileira de Estudos do Quaternário, 8., 2001, Imbé (RS). Proceedings... São Paulo: ABEQUA. Boletim de Resumos, p. 302.

SOUZA CRG, HIRUMA ST, SALLUN AEM, RIBEIRO RR \& AZEVEDO SOBRINHO JM. 2008. "Restinga": Conceitos e Empregos do Termo no Brasil e Implicações na Legislação Ambiental. São Paulo (SP): Secretaria do Meio Ambiente, Instituto Geológico, São Paulo. 104 pp.

STUEMPEL H, KAHLER S, MEISSNER R \& MILKEREIT B. 1984. The use of seismic shear waves and compressional waves for lithological problems of shallow sediments. Geophysical Prospecting, 32: 662-675.

SUGUIO K. 2010. Geologia do Quaternário e mudanças ambientais. Oficina de Textos. 408 pp.

SUGUIO K \& MARTIN L. 1976. Mecanismos de gênese das planícies sedimentares quaternárias do litoral do Estado de São Paulo. In: Congresso Brasileiro de Geologia, 29, 1976, Ouro Preto. Proceedings... Ouro Preto: SBG. p. 295-305.

SUGUIO K \& MARTIN L. 1978. Quaternary formations of the state of São Paulo and Southern Rio de Janeiro. In: International Symposium on Coastal Evolution in the Quaternary, 1978, São Paulo. Special Publication, $1,55 \mathrm{pp}$.

SUGUIO K \& TESSLER MG. 1992. Depósitos quaternários da planície costeira de Cananéia-Iguape (SP). Publicação Especial do Instituto Oceanográfico-USP, 9: 1-33.

TESSLER MG \& SOUZA LAP. 1998. Dinâmica sedimentar e feições sedimentares identificadas na superfície de fundo do sistema CananéiaIguape, SP. Revista Brasileira de 0ceanografia, 46(1): 69-83.

XIA J, MILLER RD \& PARK CB. 1999. Estimation of near-surface shear-wave velocity by inversion of Rayleigh waves. Geophysics, 64(3): $691-700$. 


\section{NOTES ABOUT THE AUTHORS}

Emilio Eduardo Moreira Barbosa. Bachelor degree in Geophysics (IAG/USP, 2009), Master's degree in Geophysics (IAG/USP, 2012). Geophysicist at Global Serviços Geofísicos Ltda.

Renato Luiz Prado. Bachelor degree in Geophysics (IGc/USP, 1981), Master's degree in Geophysics (IAG/USP, 1984) and Ph.D. in Geosciences and Environment (IGCE/UNESP, 2000). Professor of the Geophysics Department at IAG, Universidade de São Paulo.

Matheus Cafaro Arouca Sobreira. Bachelor degree in Geophysics (IAG/USP, 2011). Geophysicist at Petróleo Brasileiro S.A. - Petrobras.

Rodrigo Dias Samões. Bachelor degree in Geophysics (IAG/USP, 2011).

Célia Regina de Gouveia Souza. Bachelor degree in Geology (IGc/USP, 1983), Master's degree in Geological Oceanography (IO/USP, 1990), Ph.D. in Sedimentary Geology (IGc/USP, 1997). Researcher at the Geological Institute/SMA/SP since 1992. 